\title{
Tingkat Kepercayaan Pada Siswa Terhadap Pelayanan Guru BK (Bimbingan Konseling) di SMP Negeri 01 Turikale Maros
}

\author{
The Level of Students' Trust Towards Conseling Teacher Services (Conseling Guidelines) In SMP \\ Negeri 01 Turikale Maros
}

\author{
Isdiana Holida Bahary', Mansyur Radjab², Suparman Abdullah ${ }^{3}$ \\ ${ }^{I}$ Mahasiswa Sosiologi Fisip Universitas Hasanuddin, Makassar, Indonesia, email: isdianahb@gmail.com \\ ${ }^{2}$ Dosen Pascasarjana Sosiologi Fisip Universitas Hasanuddin, Makassar, Indonesia, email: radjabmansyur@gmail.com \\ ${ }^{3}$ Dosen Pascasarjana Sosiologi Fisip Universitas Hasanuddin, Makassar, Indonesia, email: mansosio87@yahoo.com
}

\section{A R T I C LE IN F O}

\section{How to Cite:}

Bahary, I. H., Radjab, M., \& Abdullah, S. (2020).Tingkat Kepercayaan Pada Siswa Terhadap Pelayanan Guru BK (Bimbingan Konseling) di SMP Neheri 01 Turikale Maros. Hasanuddin Journal of Sociology (HJS), 2(1), 50-60.

Keywords:

Trust, Students, Service

Kata Kunci :

Kepercayaan, Siswa,

Pelayanan

\begin{abstract}
A B S T RA C T
The background of this research was the existence of the Child Protection Law (UU No. 23 of 2002 about Child Protection) creating a serious dilemma for teachers in giving punishment to students who violate the school rules. The impact of this dilemma was the teacher became indecisive towards naughty students or those who disobeyed the school rules. Teacher indecisiveness caused the teacher's authority became lower in front of students, especially among the naughty students. They increasingly broke the school rules. This affected the trust of other students to their teacher became very susceptible. This study aimed to analyze the forms of the trust of respondent and the service of conseling teachers, the perceptions of respondents' trust towards conseling teachers, the influence of students' trust towards conseling teachers. This research used univarat and bivarat analysis by using computer program SPSS version 24. The students in this study were 78 students. The sampling technique used disproportionately stratified random sampling method. The data collection techniques used were questionnaires, observation, semi-structured interviews and documentation study. Based on the calculation results obtained there was a positive and significant relationship between service and students' trust. This means that the better the service variable, the higher the student's trust, and vice versa, the less the service variable, the lower the student's trust.
\end{abstract}

\section{A B S T R A K}

Penelitian ini dilatarbelakangi olehadanya Undang Undang Perlindungan Anak (UU No. 23 Tahun 2002 tentang Perlindungan Anak) menjadikan dilema yang berat bagi para guru dalam memberikan hukuman bagi para siswa yang melanggar aturan-aturan di sekolah. Dampak dari dilema 
tersebut, akhirnya guru menjadi kurang tegas terhadap siswa yang nakal atau melanggar tata tertib yang ada di sekolah. Ketidaktegasan guru berdampak terhadap semakin rendahnya wibawa guru di hadapan parasiswa, khususnya di kalangan siswa-siswa yang nakal. Mereka semakin seenaknya melanggar tata tertib sekolah. Sehingga trust atau kepercayaan siswa yang lain terhadap gurunya menjadi sangat rentan.Penelitian ini bertujuan untukmenganalisis tentang bentuk kepercayaan responden dan pelayanan guru BK, persepsi kepercayaan responden terhadap pelayanan guru BK, pengaruh antara kepercayaan siswa terhadap pelayanan guru BK. Penelitian ini menggunakan analisisunivaratdanbivaratmenggunakan bantuan software aplikasi computer program SPSS versi 24.Siswa dalam penelitian ini berjumlah 78siswa. Teknik Sampling menggunakan metode disproportionate stratified random sampling. Teknik pengumpulan data menggunakan teknik melalui kuesioner (angket), observasi, wawancara semiterstruktur dan studi dokumentasi. Berdasarkan hasil perhitungan diperoleh ada pengaruh positif dan signifikan antara pelayanan dan kepercayaan siswa. Artinya apabila variabel pelayanan semakin baik, maka kepercayaan siswa juga akan semakin tinggi, demikian pula sebaliknya, apabila variabel pelayanan semakin kurang, maka kepercayaan siswa juga akan semakin berkurang.

\section{PENDAHULUAN}

Fenomena pendidikan berkembang seiring dengan kemajuan teknologi, informasi, ekonomi, dan sosial budaya masyarakat. Pada masa lampau, hubungan antara guru dan murid dapat dikatakan berjarak, sementara pada saat ini guru tidak hanya berperan sebagai orang dewasa yang mendidik, tapi juga berperan sebagai orang tua yang mengasihi, dan sering kali juga menjadi tempat mencurahkan persoalan yang dihadapi oleh para siswa. Apalagi dengan adanya guru BK (Bimbingan Konseling) yang setiap harinya menangani siswa. Guru BK di tuntut untuk dapat menangani permasalahan-permasalahan dalam perilaku menyimpang yang terjadi padasiswa di sekolah. Dengan begitu, kepercayaansiswa adalah salah satu penunjang bagi guru BK untuk menanggapi dan membantu siswa untuk menyelesaikan masalah-masalah yang terkait dengan perilaku siswa di sekolah.

Menurut Falcone \& Castelfranci, kepercayaanmerupakan suatu fenomena yang dinamis, hal ini karena kepercayaan terjadi secara intrinsik pada suatu keadaan yang alamiah, dimana kepercayaanmerupakan hal yang menyangkut masalah mental yang didasarkan oleh situasi seseorang dan konteks sosialnya, misalnya ketika seseorang harus mengambil suatu keputusan, maka ia akan lebih memilih keputusan berdasarkan pilihan dari orang-orang yang lebih dapat ia percayai dari pada yang kurang ia percayai.

Berbeda dengan jaman dulu, dimana guru BK adalah guru yang sangat ditakuti oleh setiap siswa karena kegalakannya dalam mendisiplinkan murid-muridnya. Mereka takut untuk berbuat salah karena hukuman yang diberikan biasanya berupa cubitan, pukulan, bahkan tamparan. Jikapun mereka diberikan hukuman, mereka tidak berani untuk mengadu kepada orang tua bukan karena diancam oleh guru tetapi karena takut mendapatkan hukuman tambahan. 
Saat ini semenjak adanya Undang Undang Perlindungan Anak (UU No. 23 Tahun 2002 tentang Perlindungan Anak) menjadikan dilema yang berat bagi para guru dalam memberikan hukuman bagi para siswa yang melanggar aturan-aturan di sekolah. Karena hukuman berupa cubitan atau pukulan jika dilihat pada saat ini, dapat dianggap sebagai bentuk penganiayaan kepada siswa. Tindakan hukuman disiplin yang dilakukan oleh guru, yang pada dahulu kala dianggap biasa-biasa saja, kini mulai bergeser dan malah dinilai sebagai bentuk pelanggaran Hak Asasi Manusia (HAM). Hal ini bisa dilihat dari beberapa kasus yang sering diberitakan di beberapa media massa Indonesia, tentang guru yang dianggap terlalu keras pada siswa.

Guru harus menegakkan disiplin kepada para siswa, namun saat ini oleh pihak luar dalam hal ini bisa saja dari orang tua siswa atau dari LSM pembela anak untuk tidak melakukan sentuhan fisik kepada si anak, sentuhan fisik ini cenderung disalah artikan sebagai kekerasan pada anak. Hal tersebut diperkuat dengan adanya guru yang terjerat kasus penganiayaan terhadap siswanya. Contohnya lagi kasus Muhammad Samhudi, seorang guru SMP di Sidoarjo, Jawa Timur, yang memberi hukuman pada siswanya dengan memukul dan mencubit, divonis 3 bulan dengan masa percobaan 6 bulan. Hakim Pengadilan Negeri Sidoarjo, Jawa Timur menjatuhkan vonis terhadap Samhudi pada sidang yang digelar Kamis, 4 Agustus 2016. Hakim menjatuhkan hukuman tiga bulan penjara dengan enam bulan masa percobaan. (sumber: https://regional.kompas.com/read/2016/07/01/17403801/sambudi.pak.guru.yang.disidang.karena.men cubit.siswanya?page=all)

Dampak dari dilema tersebut, akhirnya guru menjadi kurang tegas terhadap siswa yang nakal atau melanggar tata tertib yang ada di sekolah. Ketidaktegasan guru berdampak terhadap semakin rendahnya wibawa guru di hadapan parasiswa, khususnya di kalangan siswa-siswa yang nakal. Mereka semakin seenaknya melanggar tata tertib sekolah. Sehingga trust atau kepercayaan siswa yang lain terhadap gurunya menjadi sangat rentan.

Tidak dapat dipungkiri bahwa banyaknya kasus kriminalisasi terhadap guru membuat guru menjadi was-was ketika akan memberikan sanksi pelanggaran disiplin kepada siswa karena khawatir melanggar Undang-undang Perlindungan anak. Akibatnya guru menjadi masa bodoh ketika melihat ada siswa yang melanggar disiplin.

Jika hal ini terus dibiarkan, maka akan menghambat pencapaian daritujuan pendidikan nasional, yaitu berkembangnya potensi peserta didik agar menjadi manusia yang beriman dan bertakwa kepada Tuhan Yang Maha Esa, berakhlak mulia, sehat, berilmu, cakap, kreatif, mandiri, dan menjadi warga negara yang demokratis serta bertanggung jawab. 
Tetapi, ketika kita melihat lebih jelas peran dan fungsi guru BK sebenarnya selama ini kita keliru bahwa guru BK haruslah orang yang tegas dan menyeramkan.

Fenti (2010) mengungkapkan bahwa pendekatan guru BK sebenarnya lebih kepada Bimbingan dan Konseling, dimana pendekatan melalui Bimbingan dan Konseling berbeda dengan pendekatan disiplin yang memungkinkan pemberian sanksi untuk menghasilkan efek jera, pananganan siswa bermasalah melalui Bimbingan Konseling sama sekali tidak menggunakan bentuk sangsi apapun, tetapi lebih mengandalkan pada terjadinya kualitas hubungan interpersonal yang saling percaya di antara konselor dan siswa yang bermasalah, sehingga setahap demi setahap siswa tersebut dapat memahami dan menerima diri dan lingkungannya, serta dapat mengarahkan diri guna tercapainya penyesuaian diri yang lebih baik.

Bila hukuman tidak lagi menyentuh tubuh, lalu apa yang disentuh? Menurut Foucault (1975), jawabannya sangat jelas, yakni jiwa.Hukuman harus menyentuh kedalam hati, pemikiran, kehendak, dan kecenderungan. Seseorang yang bersalah dihukum dengan sistem hukuman baru, yakni hukuman internal yang disesuaikan dengan perkembangan individu.

Hukuman dimaksudkan untuk mengawasi individu, menetralkan bahayanya dan mengubah kecendrungan buruknya. Melalui pengetahuan individu tersebut, mekanisme hukuman yang sah dilengkapi dengan pembenaran yang berdasarkan bukan hanya pada kesalahan, tetapi juga pada individu, bukan hanya pada apa yang diperbuat, tetapi pada individu itu sendiri.

Foucault menganjurkan agar analisis atas penghukuman dibersihkan dari anggapan umum bahwa hukuman berfungsi untuk mengurangi kesalahan. Hukuman harus ditempatkan bukan hanya sebagai mekanisme negatif yang menjadikan mampu menekan, menghalangi, mencegah, menghilangkan kejahatan, tetapi harus dikaitkan juga dengan serangkaian mekanisme pelatihan, pengontrolan, yang membawa akibat positif dan berguna. Demi tujuan itu, dikembangkan teknik pendisiplinan.disiplin yang dimaksud adalah mengoreksi dan mendidik.

Sehingga dengan adanya UU Perlindungan Anak ( UU No. 23 Tahun 2002 tentang Perlindungan Anak) guru masih dapat mendisiplinkan siswa bermasalah tanpa memberikan sangsi fisik.

Berdasarkan masalah yang telah penulis paparkan diatas, maka penulis tertarik untuk melakukan penelitian dengan judul "Tingkat Kepercayaan Siswa Terhadap Pelayanan Guru BK (Bimbingan Konseling) di Sekolah SMP Negeri 01 Turikale Maros". 


\section{METODE PENELITIAN}

\subsection{Lokasi dan Rancangan Penelitian}

Penelitian ini dilaksanakan di SMP Negeri 01 Turikale Maros yang berada di Kabupaten Maros.Jenis Penelitian ini menggunakan metodekuantitatif.

\subsection{Populasi dna Sampel}

Populasi adalah siswakelastiga di SMP Negeri 01 TurikaleMaros. Sampel sebanyak 78 siswayang dipilih secara disproportionate stratified random sampling. Siswakelastiga dipilih sebagai sampel karena siswakelastigasudahlebihbanyakmendapatkanpelayanan yang diberikan guru BK mulai dari baru masuk sekolah hingga akan mengikuti ujian akhir sekolah dan nasional.

\subsection{Metode Pengumpulan Data}

Metode pengumpulan data yang digunakan dalam penelitian ini adalah dengan menyebar kuesioner atau angket kepada 78 siswa, kemudian melakukan studi dokumentasi untuk mengetahui informasi dan data-data yang mendukung penelitian ini. Dan peneliti melakukan observasi pengamatan langsung kepada siswaSMP Negeri 01 TurikaleMaros.

\subsection{Analisis Data}

Teknik analisis data dalam penelitian ini menggunakan analisis data kuantitatif secara univariat dan bivariat menggunakan bantuan software aplikasi computer program SPSS versi 24.

\section{HASIL PENELITIAN}

\subsection{Bentuk Kepercayaan Responden dan Pelayanan Guru BK}

Menurut Bryk dan Schneider, (2003) orang yang memiliki trust ditandai dengan:

1. Consistency, yaitu adanya ketetapan dalam memberikan pesan kepada orang lain tanpa membedakan satu sama lain. Dengan demikian tingkat keyakinan seseorang akan semakin besar karena adanya rasa aman dari ketetapan tersebut yang menghasilkan suatu kepercayaan.

2. Compassion, yaitu kepedulian yang tinggi penting dalam hubungan saling percaya. Dengan saling berkasih saying menyisaratkan bentuk perlindungan sehingga tidak akan muncul perasaan merugikan orang lain.

3. Communication, yaitu berfokus pada bagaimana berbagi informasi yang mana informasi tersebut tidakakan dieksploitasi bebas. Dengan kata lain, hal ini mengacu pada keterbukaan sebagai strategi dalam menjaga kerahasiaan yang bersifat pribadi.

4. Competency, yaitu adanya tanggung jawab dan konsitensi seseorang dalam suatu pekerjaan 
dan seberapa baik hasil yang diperoleh.

Menurut David Wijaya (2012) mengutip pernyataan Parasuraman dkk (1998), terdapat lima dimensi SERVQUAL yang dikenal dengan istilah RATER. RATER ini dapat diterapkan dalam dunia pendidikan dan terdiri atas unsur-unsur berikut ini:

1. Reliability (Keandalan)

Reliability yaitu keandalan/ kemampuan sekolah untuk menyediakan jasa Pendidikan sesuai dengan janji secara akurat dan terpercaya. Kinerja sesuai harapan pelanggan jasa Pendidikan berupa ketepatan waktu, pelayanan yang seragam untuk setiap pelanggan jasa Pendidikan tanpa kesalahan, sikap simpatik dan keakuratan yang tinggi.

2. Assurance (Jaminan)

Assurance yaitu pengetahuan, kesopansantunan serta kemampuan karyawan sekolah untuk menumbuhkan rasa percaya pelanggan jasa Pendidikan pada sekolah, meliputi komunikasi, kepercayaan, keamanan, kompotensi dan sopan santun.

3. Tangible (Bukti Fisik)

Tangible adalah kemampuan sekolah untuk menunjukkan keberadaan dirinya pada pihak eksternal sekolah, meliputi fasilitas fisik (gedung, Gudang dan lain-lain), perlengkapan dan peralatan pendidikan yang digunakan serta penampilan karyawan sekolah.

\section{Empathy (Empati)}

Sekolah mampu memberikan perhatian yang tulus dan pribadi kepada pelanggan jasa Pendidikan dengan memahami keinginan pelanggan jasa pendidikan. Sekolah juga diharapkan memiliki pengertian dan pengetahuan tentang pelanggan jasa pendidikan, memahami kebutuhan pelanggan jasa pendidikan secara khusus, sertamemilikiwaktuoperasijasapendidikan yang nyaman bagi pelanggan jasa pendidikan.

5. Responsivines (Ketanggapan),

Responsivines yaitu kebijakan untuk membantu serta memberikan jasa kependidikan yang cepat dan tepat kepada pelanggan jasa pendidikan.

\subsection{Persepsi Kepercayaan Responden terhadap Pelayanan Guru BK}

Berikut tabel yang memuat hasil rekapitulasi skor total persepsi responden tentang keempat aspek kepercayaan: konsistensi, kepedulian, komunikasi, dan kompetensi.

Tabel 1. Rekapitulasi Skor Total Persepsi Responden tentang Kepercayaan Siswa terhadap Guru BK di SMP Negeri 01 Turikale Maros

\begin{tabular}{llrl}
\hline No & \multicolumn{1}{c}{ Aspek Kepercayaan } & JumlahSkor & \% \\
\hline 1 & Konsistensi & 2113 & 25,0 \\
2 & Kepedulian & 2208 & 26,2 \\
3 & Komunikasi & 1919 & 22,8 \\
\hline
\end{tabular}




\begin{tabular}{lll}
\hline $4 \quad$ Kompetensi & 2195 & 26,0 \\
\hline Jumlah & $\mathbf{8 4 3 5}$ & $\mathbf{1 0 0 , 0 0}$ \\
\hline
\end{tabular}

Berdasarkan Tabel 4.5 terlihat bahwa skor total persepsi responden tentang kepercayaan siswa terhadap guru BK sebesar 8435 (100,00\%). Kemudian dibuat kategorisasinya : sangat tinggi, tinggi, rendah, dan sangat rendah. Bahwa hal ini menunjukkan dari empat aspek konsistensi, kepedulian, komunikasi, dan kompetensi menghasilkan tinggkat kepercayaan yang tinggi. Responden berpersepsi tentang kepercayaan dengan menghitung interval tiap-tiap kategori dengan cara menghitung :

Skor Tertinggi = Nilai Tertinggi $\mathrm{x}$ Jumlah Soal $\mathrm{x}$ Jumlah Responden

$=4 \times 40 \times 78=12.480$

Skor Terendah $=$ Nilai Terendah $\mathrm{x}$ Jumlah Soal $\mathrm{x}$ Jumlah Responden

$=1 \times 40 \times 78=3120$

Interval $\quad=$ (nilai tertinggi- nilai terendah) $:$ Kelas Interval $=(12.480-3120): 4=2340$

Berdasarkan rumus di atas, didapatkan hasil skor interval kepercayaan siswa adalah 2340. Dari hasil interval tersebut, maka:

$10.140-12.480=$ Sangat Tinggi

$7800-10.139=$ Tinggi

$5460-7799=$ Rendah

$3120-5459=$ Sangat Rendah

Secara keseluruhan, rekapitulasi responden tentang kepercayaan siswa terhadap guru BK di SMP Negeri 01 Turikale Maros adalah 8435 yang berarti tingkat kepercayaan siswa tinggi terhadap guru BK di SMP Negeri 01 Turikale Maros.

Persentase posisi skor total kepercayaan responden berdasarkan aspek kompetensi pada diagram tabel diperoleh melalui perhitungan berikut :

$(\%)=\frac{\text { Total skor pada Kepercayaan }}{\text { skor maksimum }} \times 100 \%$

$(\%)=\frac{8435}{12480} \times 100 \%$

$(\%)=67,6 \%$

Proses perhitungan yang dilakukan, menghasilkan skor jawaban responden. Secara keseluruhan skor jawaban responden terhadap kepercayaan sebesar 8435 (67,6 \%) termasuk dalam kategori positif maksudnya bahwa responden cukup percaya kepada guru BK. Tetapi masih ada 32,4\% 
responden termasuk dalam kategori negatif, ini menunjukkan bahwa masih ada Sebagian responden yang kurang percaya terhadap guru BK.

Hal ini, dapat diartikan bahwa kepercayaan siswa terhadap guru BK dikategorikan tinggi $(67,6$ \%). Meskipun demikian, masih ada Sebagian kecil responden yang tidak percaya terhadap guru BK $(32,4 \%)$. Jika dilihat dari persentase negatif, kita sebaiknya tidak mengabaikan hasil tersebut karena kepercayaan responden terhadap guru BK apa lagi jika di dalamnya terdapat responden yang bermasalah.

\subsection{Pengaruh antara Kepercayaan Siswa Terhadap Pelayanan Guru BK}

Berdasarkan analisis regresi yang dilakukan dengan menggunakan bantuan SPSS versi 24 diperoleh output sebagai berikut:

Tabel 2. Hasil Uji Korelasi Variabel Pelayanan dan Kepercayaan

\begin{tabular}{llll}
\multicolumn{4}{c}{ Correlations } \\
\hline & & Pelayanan & Kepercayaan \\
\hline Pelayanan & Pearson Correlation & 1 & $.622^{* *}$ \\
& Sig. (2-tailed) & & .000 \\
& $\mathrm{~N}$ & 78 & 78 \\
Kepercayaan & Pearson Correlation & $.622^{* *}$ & 1 \\
& Sig. (2-tailed) & .000 & \\
& $\mathrm{~N}$ & 78 & 78 \\
\hline
\end{tabular}

**. Correlation is significant at the 0.01 level (2-tailed).

Berdasarkan hasil perhitungan diperoleh nilai koefisien korelasi $\mathrm{R}=0,622$, dan Probabilitas $(\mathrm{P})=$ 0,000 (dimana $\mathrm{P}<0,01$ ), maka dapat disimpulkan bahwa ada pengaruh positif dan signifikan antara pelayanan dan kepercayaan siswa. Artinya apabila variabel pelayanan semakin baik, maka kepercayaan siswa juga akan semakin tinggi, demikian pula sebaliknya, apabila variabel pelayanan semakin kurang, maka kepercayaan siswa juga akan semakin berkurang.

\section{KESIMPULAN}

Berdasarkan hasil perhitungan diperoleh nilai koefisien korelasi $\mathrm{R}=0,622$, dan Probabilitas $(\mathrm{P})=$ 0,000 (dimana $\mathrm{P}<0,01$ ), maka dapat disimpulkan bahwa ada pengaruh positif dan signifikan antara pelayanan dan kepercayaan siswa. Artinya apabila variabel pelayanan semakin baik, maka kepercayaan siswa juga akan semakin tinggi, demikian pula sebaliknya, apabila variabel pelayanan semakin kurang, maka kepercayaan siswa juga akan semakin berkurang.

Ada beberapa siswa yang ditemukan masih kurang dalam melihat pelayanan BK. takut dalam menyampaikan pendapat, tidak berani mengungakapkan pendapat.Pelaksanaan layanan bimbingan konseling tersebut sudah berjalan namun belum dapat dikatakan sempurna dikarenakan kurangnya 
fasilitas yang mampu menunjang keberhasilan pelaksanaan layanan tersebut, dan kurangnya jam BK disekolah tersebut. Pelaksanaan layanan tersebut dapat dilakukan apabila adanya waktu luang dan hal itu menjadi hal yang urgensi dan mesti diselesaikan dengan cepat.

Layanan bimbingan konseling yang diberikan oleh guru pembimbing kepada siswa,dengan mengikuti tahapan-tahapan bimbingan kelompok, meskipun adanya terjadi hambatan-hambatan seperti sering ditemui siswa kurang fokus mengikuti atau mendengarkan bimbingan yang disampaikan.

\section{SARAN}

Peneliti akan memberikan saran yang akan menjadi masukan dan pertimbangan untuk peserta didik dalam tingkat Kepercayaan Siswa SMP 01 Turikale Maros terhadap pelayanan BK, antara lain :

1. Kepala sekolah selaku pemegang kebijakan otonomi sekolah hendaknya:

a. Memberikan ruang yang cukup kepada konselor untuk mengembangkan diri dengan usaha-usaha peningkatan kompetensinya masing-masing dan meningkatkan pengadaan sarana prasarana BK

b. Menyelenggarakan kegiatan-kegiatan workshop untuk konselor dalam rangka pengembangan dan peningkatan kompetensi yang berdampak meningkatnya mutu dan efektititas layanan bimbingan konseling.

2. Konselor selaku pembimbing konseling SMP 1 Turikale Maros, diharapkan:

a. Selalu meningkatkan kompetensi, mengikuti perkembangan layanan konseling dengan mengikuti pelatihan atau workshop yang terkait dengan efektifitas bimbinga nkonseling.

b. Terus termotivasi untuk selalu memberi layanan bimbingan dan konseling demi tercapainya tujuan pembelajaran serta meningkatnya mutu pendidikan.

3. Kepada siswa dan siswi di SMP 1 Turikale Maros

Hendaknya mempunyai perhatian terhadap dirinya sendiri misalnya apabila ada masalah yang sulit dipecahkan secara sendirilah hendaknya berkonsultasi pada guru atau orang lain yang dapat membantu memecahkan masalah yang dihadapinya. Selain itu siswa dan siswi di harapkan dapat lebih memotivasi diri untuk lebih giat belajar dan selalu berusaha semaksimal mungkin dalam belajar baik belajar sendiri maupun belajar kelompok. 


\section{DAFTAR PUSTAKA}

Abdullah Idi. (2011). Sosiologi Pendidikan. Jakarta: PT Raja Grafindo Persada.

Alfitri. (2011). Community Development: Teori dan Aplikasi. Yogyakarta: Pustaka Pelajar

Anthony S. Bryk and Barbara Schneider. (2003) Trust in School: A Core Resource for School Reform

Astrid S. (2003). Pengantar Sosiologi dan Perubahan Sosial . Grafindo Persada. Jakarta

Coleman J. S. 1988. Social Capital in The Creation of Human Capital. Amercan Journal of Sociology 94 (supplement): S95-S120

Damsar. Pengantar Teori Sosiologi. Jakarta: Fajar Dunia

Fadjar. (1999). Reorientasi Pendidikan Islam. Jakarta: Fajar Dunia

Fenti Hikmawati. (2010). Bimbingan dan Konseling.Jakarta: PT Raja Grafindo Persada.

http://regional.liputan6.com/read/2575357/5-konflik-pelik-guru-versus-siswa-berujung-pidana September 2017)

http://www.ascd.org/publications/educational-leadership/mar03/vol60/num06/Trust-in-School@-ACore-Resource-for-School-Reform.aspx (06 September 2017)

Jousairi Hasbullah. (2006). Social Capital. Jakarta: MR-United Press Jakarta

Laksamana, Arsono. (2002). Pengaruh Saling Ketergantungan, Kepercayaan, dan Keselarasan Tujuan Terhadap Kooperasi dan Kinerja Perusahaan Manufaktur pada Hubungan Kontraktual dengan Pemasoknya”. Jurnal Akuntansi \& Keuangan.

Mansyur Radjab. (2014). Bahan Ajar Metode Penelitian Kualitatif. Jurusan Sosiologi FISIP UNHAS. Makassar.

Mansyur Radjab. (2014). Bahan Ajar Sosiologi Pendidikan. Jurusan Sosiologi FISIP UNHAS. Makassar

Moh Nazir. (2009). Metode Penelitian Kuantitatif. Bandung: Alfabeta.

Muhammad Noor Syam. (1986). Filsafat Pendidikan dan DasarPendidikan Pancasila. Surabaya: Usaha Nasional.

Nanang Martono. (2010). Metode PENELITIAN Kuantitatif. Jakarta: Karisma Putra Utama Offset.

Ojha Amithb, M.P. Gupta. (1998). Does E-Government Enhance Trust ingovernment. Computer Society of India.

Ratnasari, Murni. Optimalisasi Modal Sosialdalam Pembangunan KesejahteraanPekerjaOutsourchingdi PT. Aneka Tambang Unit BisnisPertambanganNikelPomala Sulawesi Tenggara.(2014). TesisSosiologi.UniversitasHasanuddin.

Sugiyono. (2007). Metode Penelitian Kuantitatif Kualitatif dan R\&D. Bandung: Alfabeta

Sugiyono. (2008). Metode Penelitian Kuantitatif Kualitatif dan R\&D. Bandung: Alfabeta

Sugiyono.(2011). Metode Penelitian Kuantitatif Kualitatif dan R\&D. Bandung: Alafabeta

Tschannen-Moran, M., Hoy, A. W., \& Hoy, W.K, (1998).Teacher efficacy: Its meaning and measure. Review of Educational research, 68(2), 189-190

Wijaya, David. (2012). Pemasaran Jasa Pendidikan. Jakarta: Salemba Empat. 
Woolfolk hoy, A. \&Tschannen-Moran (1999). Implications of cognitive approaches to peer learning for teacher education.In A.M. O’Donnell \& A. King (Eds.) Cognitive Perspectives on peer learning.Mahwah, NJ: Lawrence Erlbaum.

Woolfolk Hoy, A. \&Tschannen-Moran (2001). Collaboration and the need for trust. Journal of educational Administration, 39, 308-331.

Zainuddin Maliki. (2008). Sosiologi Pendidikan. Yogyakarta: Gajah Mada University Press.

Zulganef dan Murni.(2008). Hubungan Kepuasan dan Kepercayaan Mahasiswa terhadap Lembaga Pendidikan Tinggi dengan Keinginan untuk Membujuk Calon Mahasiswa melanjutkan Studi ke Perguruan Tinggi. 